\title{
BEHAVIOR OF LIGHTWEIGHT SELF-COMPACTED CONCRETE USING ATTAPULGITE STONE AS AGGREGATE AND SUBJECTED TO AXIAL LOAD
}

${ }^{\star}$ Heba S. Qassim ${ }^{1}$

\author{
Wissam K. AL-Saraj ${ }^{1}$
}

1) Civil Engineering Department, College of Engineering, Mustansiriyah University, Baghdad, Iraq

\begin{abstract}
This paper presents experimental studies of rectangular concrete beam behaviors under axial load and bending loads and investigating the possibility of producing Lightweight Self-Compacting Concrete (LWSCC) by using the Attapulgite stone with a bulk density of about $776 \mathrm{~kg} / \mathrm{m}^{3}$. The experimental work included (5) specimens which included using the silica fume by $10 \%$ and $15 \%$ as an addition to the mixture $\mathrm{M} 2$ and $\mathrm{M} 3$. The shear span to effective depth $(\mathrm{a} / \mathrm{d})$ of beams was $(2.5,2.75$, and 3.00). The test results showed an improvement in the mechanical properties of specimens containing silica fume by $15 \%$, which was tested at 28 days. The first crack and the ultimate load were decreasing with increasing $(a / d)$ ratios. Experimental results indicate a significant improvement in the properties of concrete and its resistance to shear stresses, as the axial load improves the shear capacity and reduces the shear failure in the (LWSCC).
\end{abstract}

Keywords: Lightweight self-compacting concrete, Attapulgite, silica fume, shear span to effective depth

\section{Introduction}

Concrete is of the most important available materials for construction in all over the world the concrete construction is characterized durability, resistance to fire and low maintenance costs [1]. Lightweight aggregate concrete is a type concrete, it has been used in many applications such as bridges off shore oil platforms, pre-stressed structural elements, multi-story building and floors [2]. In the last years, there has been a need to develop concrete performance in durability, strength and flow ability this leads to the innovation of a new type of concrete called Self-Compacting Concrete (SCC).SCC differs from ordinary concrete in that it compacts by mean of its self- weight without the need for external or internal vibrators so it can fill all parts of the mold and segregation resistance [3]. Various types of SCC have been developed to meet the construction requirements. One of the most important innovations is the combination of lightweight concrete (LWC) and (SCC) to produce Lightweight Self-Compacting Concrete (LWSCC) can maximize the benefits and applications of concrete. Based on the previous studies, Attapulgite clay was used as a coarse aggregate to produce lightweight concrete that was excellent by its light weight and fire resistance. Al-Nuaimi [4] was studied The effect of using Attapulgite with a replaced rate of(580)\% with cement weight on the mechanical properties of Portland cement. The results showed that the compressive strength was better $5 \%$ and $15 \%$ at ages $(28,90,180)$ days. The replacement rate of $25 \%$ was the highest compressive strength at ages 90 and 180 days. Jar- Allah [5] study the using of Thermostone

*Corresponding Author: hess7607@gmail.com 
aggregates of size $9.5 \mathrm{~mm}$ and Porcelinite aggregates size $9.5 \mathrm{~mm}$ in addition to using high reactivity metakaoline (HRM) and silica fume (SF) on the mechanical properties of LWSCC .Two different of w/c ratios were used 0.32 and 0.35.the results showed the (HRM) which is better than silica fume in production of LWSCC. The values of compressive strength and air dry density at age 28 days foe w/c 0.32 of LWSCC with Porcelinite aggregates were better than of the Thermostone aggregates. Khandaker M [6] study the possibility of producing lightweight aggregates concrete by using volcanic pumice (VP) stone as a substitute material for cement and coarse aggregate. Chao-wei et al., [7] discussed shear behaviors of longitudinally reinforcement lightweight concrete made from the sedimentary lightweight aggregate and compared them with normal weight concrete. The variables included in this study are compressive strengths of 23,43 and $53 \mathrm{MPa}$ in addition to shear span to the effective depth $(\mathrm{a} / \mathrm{d})$ of $(1.5,2,2.5,3)$. The test results were compared with ACI 318 Code, the comparisons show that the shear forces for (LWC) and (NWC) are within the acceptable limits of ACI 318 Code. S.Garcia et al.,[8] This study discussed the shear behavior of reinforced concrete beams without transverse reinforcement. Two types of concrete were produced, the first is reference conventional concrete (RCC) and the second is lightweight self-compaction concrete (LWSCC). During the search, the longitudinal reinforcement was determined $(0.89,1.27,1.68) \%$ and the shear to the effective depth $(\mathrm{a} / \mathrm{d})$ was $(1.87,2.71)$. The results showed that the shear resistance of the beam was directly affected by the longitudinal reinforcement ratio regardless of the concrete type or $(\mathrm{a} / \mathrm{d})$, the higher the longitudinal reinforcement ratio, the greater the shear resistance of the beam. The results also showed that LWSCC beams have a shear resistance less than RCC.

The main objectives of this study the effect of axial load on behavior of LWSCC contain Attapulgite stone as a coarse aggregate. Two variables were used, first the different value of compressive strength of concrete by using two different values of addition of silica fume $10 \%$ and $15 \%$. While second variable was using different value of shear span ratio $(\mathrm{a} / \mathrm{d})$.

\section{Material}

\subsection{Cement}

Ordinary Portland Cement (OPC) was used in this research .cement was achieved with Iraq Specification limits (IQS) No.5/ 1984 [9].

\subsection{Fine Aggregate (sand)}

Sand of $4.75 \mathrm{~mm}$ maximum size is used as a fine aggregate in (LWSCC) mixes. The sand used during this research was conforms to (IQS) No.45/1984[10].

\subsection{Coarse Aggregate (Attapulgite)}

Attapulgite stone from Tar AL-Najaf region the raw material for the production of the Attapulgite aggregate. The bulk density of the aggregate was $776 \mathrm{~kg} / \mathrm{m} 3$.Attapulgite stone were crushed to give a final product of about $14 \mathrm{~mm}$ a maximum coarse aggregate size. The crushed stone was sieved by a standard sieve conform to the (IQS) 45/1984[10]. Table (1) shown the grading of Attapulgite aggregate. Attapulgite is burned at a temperature of $1100 \mathrm{C}^{\circ}$ for half an hour to give the porous structure of the stone. Then the stone is soaked with sodium Hypochlorite solution for 24 hours. The Attapulgite stone treated with Sodium Hypochlorite solution increased the stone strength and improved abrasion resistance and specific gravity. In addition to improving the mechanical properties of concrete by increasing the resistance and hardness of the stone. 
Table 1. Sieve analysis of Attapulgite stone

\begin{tabular}{lll}
\hline Sieve & Attapulgite & Limit of \\
Size $(\mathrm{mm})$ & $(\%$ passing) & IQS45/1984 \\
20 & 100 & 100 \\
14 & 90 & $90-100$ \\
10 & 53.75 & $50-85$ \\
5 & 9 & $0-10$ \\
\hline
\end{tabular}

\subsection{Chemical Admixture}

A high performance concrete super-plasticizer (Visco-Crete 5930L) is used in this research complies to ASTM C494 [11] Type A and F. Table 2. Shows properties of Super-plasticizer.

Table 2. Properties of super-plasticizer

\begin{tabular}{ll}
\hline Commercial Name & Visco-Crete 5930L \\
Form & Viscous liquid \\
Color & Light brown \\
Relative density & $0.01-1.083 \mathrm{Kg} / \mathrm{m}^{3}$ \\
$\mathrm{PH}$ & $4-6$ \\
Viscosity & $128 \mu 30 \mathrm{cps} @ 20^{\circ} \mathrm{C}$ \\
Labeling & No hazard label required \\
Transport & Not classified as dangerous \\
Chlorides & Free from chlorides \\
\hline
\end{tabular}

*Supplied by the Manufacturer

\subsection{Mineral Admixture}

\subsubsection{Limestone Powder}

Locally, this mineral is called to as (Al-Gubra). The cement in LWSCC mixes is generally replaced by limestone powder to enhance a properties of concrete.

\subsubsection{Silica Fume (SF)}

Silica fume was used in a ratio of $10 \%$ and $15 \%$ in this study the chemical analysis of silica fume was conformed to the requirements of ASTM C1240[12]. Table (3) shows the chemical composition of silica fume.
Table 3. The chemical composition of silica fume

\begin{tabular}{lll}
\hline $\begin{array}{l}\text { Chemical } \\
\text { composition }\end{array}$ & $\begin{array}{l}\text { Oxide } \\
\text { Content } \%\end{array}$ & $\begin{array}{l}\text { Limit } \\
\text { specification } \\
\text { requirements }\end{array}$ \\
$\mathrm{Cao}$ & 0.5 & - \\
$\mathrm{Fe} 2 \mathrm{O} 3$ & 1.4 & - \\
$\mathrm{A} 2 \mathrm{O} 3$ & 0.5 & - \\
$\mathrm{SiO} 2$ & 92.1 & $85(\mathrm{~min})$ \\
$\mathrm{Mgo}$ & 0.3 & - \\
$\mathrm{SO} 3$ & 0.1 & - \\
$\mathrm{K} 2 \mathrm{O}$ & 0.7 & - \\
$\mathrm{Na} 2 \mathrm{O}$ & 0.3 & - \\
L.O.I & 2.8 & $6(\max )$ \\
\hline
\end{tabular}

*Supplied from manufacturers

\subsection{Water}

Tap water was used in all concrete mixes.

\section{Details of Tested Beams}

Five lightweight self-compacting reinforced concrete beams of rectangular sections in dimensions, $200 \mathrm{~mm} \times 120 \mathrm{~mm}$ with length $1500 \mathrm{~mm}$, as shown in Figure 1.The beams of LWSCC were reinforced in the tension zone by using 2 bars of $16 \mathrm{~mm}$ diameter. The stirrup reinforcement was $6 \mathrm{~mm}$ bars placed at spacing $80 \mathrm{~mm}$ center to center the compression area was reinforced with a diameter of $4 \mathrm{~mm}$ to fixed the stirrups. The (B1R) was cast as a reference beam, the (B2 and B3) were cast by using silica fume at rates $(10 \%$ and $15 \%)$ and the (B4 and $\mathrm{B} 5)$ discuss the effect of shear span to effective depth. the beams were tested by two points load. Table 4 . Illustrates the specification and tensile test results of steel bars are accordance with standard specifications for steel reinforcement ASTM A615-86 [13] and ASTM A82-05 [14]. 


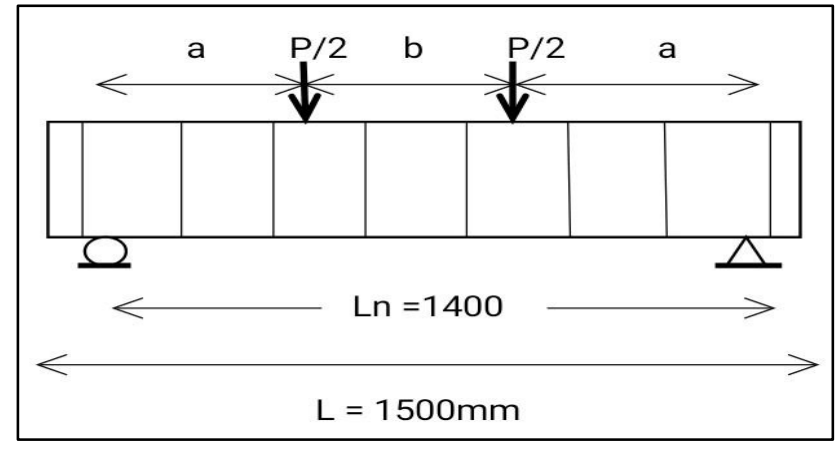

(a)

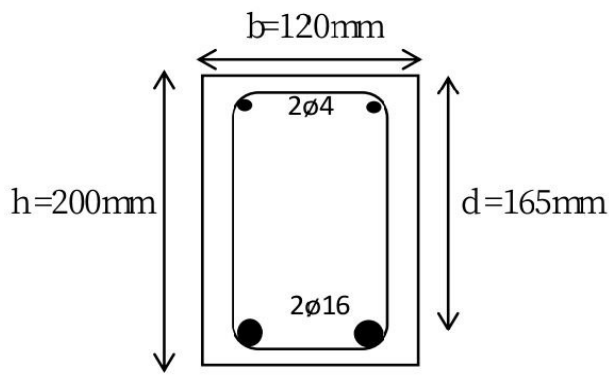

(b)

Figure 1. Details of tested beams: (a) beam span and (b) cross-section

Table 4. Specification and tensile test results of steel bars

\begin{tabular}{|c|c|c|c|}
\hline Nominal & Yield & Ultimate & Elongation \\
\hline $\begin{array}{l}\text { Diameter } \\
(\mathrm{mm})\end{array}$ & $\begin{array}{l}\text { Stress } \\
(\mathrm{MPa})\end{array}$ & $\begin{array}{l}\text { Strength } \\
\text { (MPa) }\end{array}$ & $\%$ \\
\hline 6 & 655 & 831 & - \\
\hline 16 & 445 & 635 & 10.21 \\
\hline
\end{tabular}

\section{Experimental Works}

Table 5. shows the details of LWSCC beams that were used in this research include cement500 $\mathrm{kg} / \mathrm{m}^{3}$, the sand $850 \mathrm{~kg} / \mathrm{m}^{3}$, Attapulgite stone 290 $\mathrm{kg} / \mathrm{m}^{3}$, Limestone $75 \mathrm{~kg} / \mathrm{m}^{3}$, w/c 0.3 , and Superplasticizer $14 \mathrm{l} / \mathrm{m}^{3}$.the BR1 was the reference beam while the other beams were used to study the effect of using the silica fume and shear span to effective depth $(\mathrm{a} / \mathrm{d})$ of LWSCC. The beam was subjected to an axial load using a steel frame, in order to achieve the requirements of the axial force test. The beam is fixed inside the steel frame then, the beam placed vertically on the test machine to applied an axial force of $100 \mathrm{KN}$. after that, the beam is placed horizontally to applied two point loads until failure. This test was conducted to study the behavior of the beams under the axial force, as this test simulates the reality through the exposure of the buildings to the axial force caused by the pressure of the walls of the buildings next to it. Figure 2. Shows the process of applying the axial load and the two point loads to the beams using the steel frame.

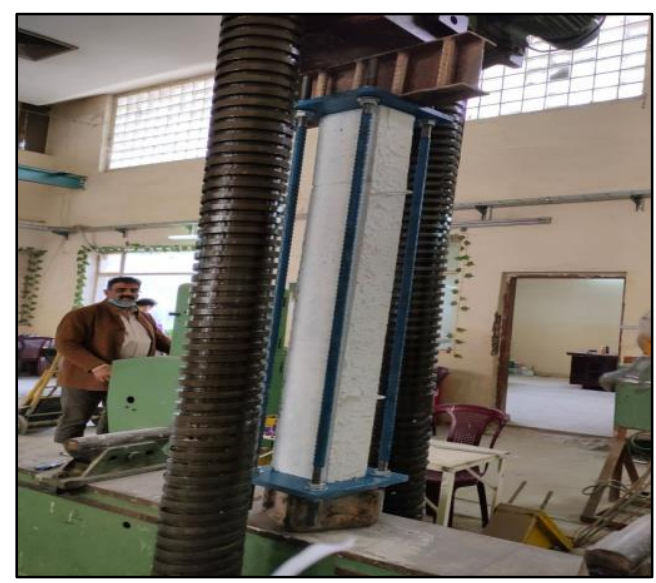

(a)

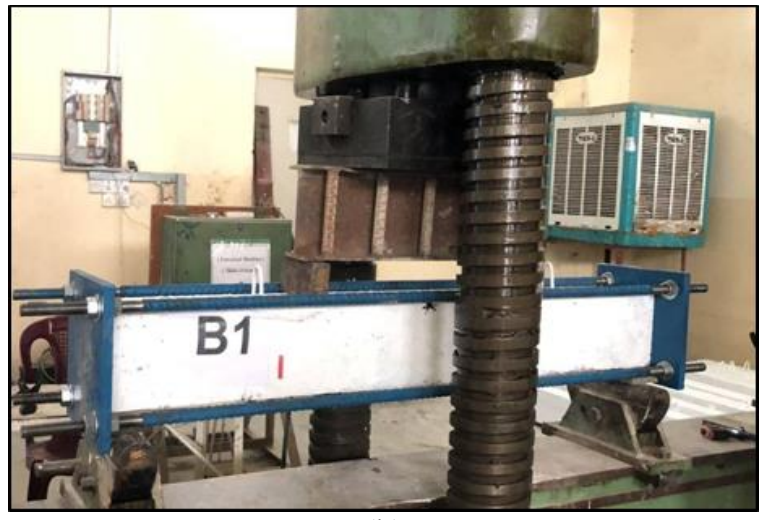

(b)

Figure 2. Applying the axial load and the two point loads to the beams

Table 5. Details of LWSCC Tested beams

\begin{tabular}{llll}
\hline Mix/Beam & Silica Fume & $\%$ & $(\mathrm{a} / \mathrm{d})$ \\
Symbol & $\%$ & Super & \\
M1R/BR1 & 0 & 0.7 & 2.5 \\
M2/B2 & 10 & 0.7 & 2.5 \\
M3/B3 & 15 & 0.7 & 2.5 \\
M4/B4 & 0 & 0.6 & 2.75 \\
M4/B5 & 0 & 0.6 & 3.00 \\
\hline
\end{tabular}




\subsection{Tests of Fresh Concrete}

Tests of fresh concrete were used to determine the workability for reference concrete. Slump Flow test and T500mm,L-box, V-funnel are the available tests in the materials laboratory of the Mustansiriyah University as shown in figure 2.Slump flow test, L-box test and V-Funnel test were used to characterize the properties of LWSCC (passing ability, filling ability and segregation resistance) all these tests were performed according to EFNARC 2005[15].
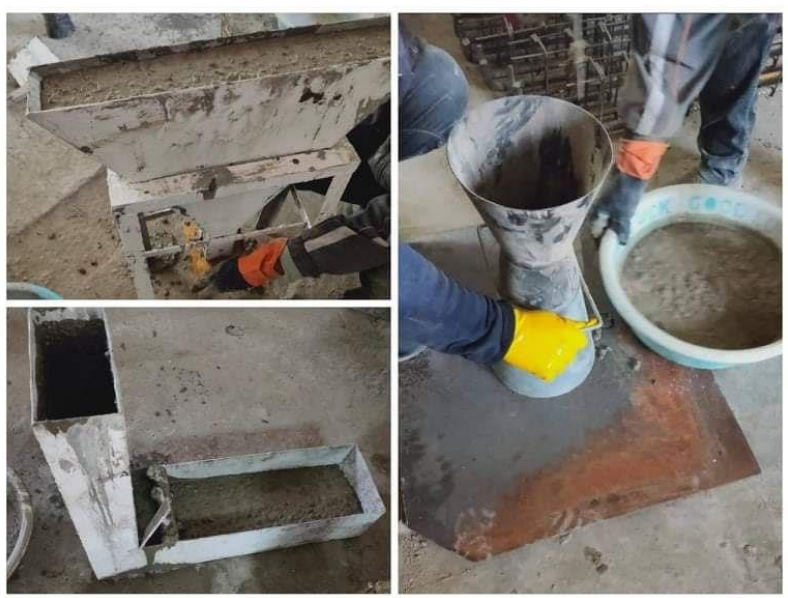

Figure 3. Tests of fresh concrete

\section{Results}

\subsection{Results of Fresh LWSCC}

The concrete is considered as LWSCC if its fresh properties are in conformity with the specification such as EFNARC [15]. Table 6. Shown the test results of the fresh concrete and limitations of EFNARC.

Table 6. Test results of fresh LWSCC

\begin{tabular}{llll}
\hline Test & Unit & Test result & Range[15] \\
& & & \\
Slump flow & $\mathrm{mm}$ & 760 & $650-800$ \\
T50 & $\mathrm{sec}$ & 2.89 & $2-5$ \\
V-funnel & $\mathrm{sec}$ & 8.3 & $6-12$ \\
L-box & $\%$ & 1.0 & $0.8-1.0$ \\
\hline
\end{tabular}

\subsection{Mechanical Properties}

The results of mechanical properties of LWSCC were illustrated in Table 7. and Figure 4. The maximum increase in compressive strength $\left(f f^{\prime}\right)$ was $22 \%$ by the addition of $15 \%$ of silica fume (M3).The reference value of compressive strength was 27.5 $\mathrm{MPa}$,while the maximum value for this test was $33.6 \mathrm{MPa}$. The reference value of splitting strength $(f t)$ cylinders for the mixture of lightweight Self-Compacting Concrete was $3.51 \mathrm{MPa}$, while the maximum value calculated for this test was $4.59 \mathrm{MPa}$ with $15 \%$ addition by silica fume, the maximum percentage increasing of this test was $31 \%$ in the mixture (M3). The maximum percentage increasing of modulus of rupture $(f r)$ was $21 \%$ at addition $15 \%$ of silica fume (M3). The modulus of elasticity $(E c)$ was increased by $17 \%$ with same mixture (M3). The mechanical tested of compressive strength, the splitting strength, modulus of rupture and modulus of elasticity of LWSCC were carried according to ASTM C39/C39-05 [16], ASTM C496-04 [17], ASTM C78-84 [18] and ASTMC469[19] respectively.

Table 7. Result of mechanical properties of LWSCC

\begin{tabular}{lcccc}
$\begin{array}{l}\text { Mix } \\
\text { symbol }\end{array}$ & $\begin{array}{c}\mathbf{f c ́} \\
(\mathbf{M P a})\end{array}$ & $\begin{array}{c}\mathbf{f t} \\
(\mathbf{M P a})\end{array}$ & $\begin{array}{c}\mathbf{f r} \\
(\mathbf{M P a})\end{array}$ & $\begin{array}{c}\mathbf{E c} \\
(\mathbf{G P a})\end{array}$ \\
M1R & 27.5 & 3.51 & 4.87 & 18.113 \\
M2 & 31.7 & 4.20 & 5.36 & 20.149 \\
M3 & 33.6 & 4.59 & 5.91 & 21.216 \\
M4 & 25.5 & 3.11 & 4.07 & 18.003 \\
\hline
\end{tabular}

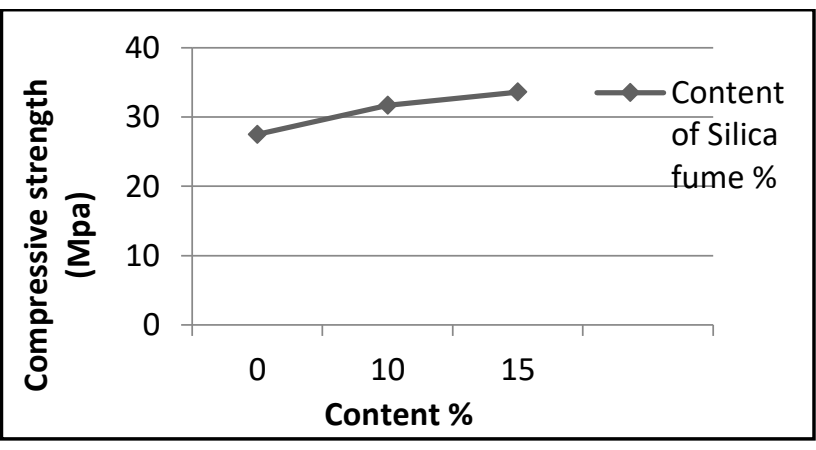

(a) 


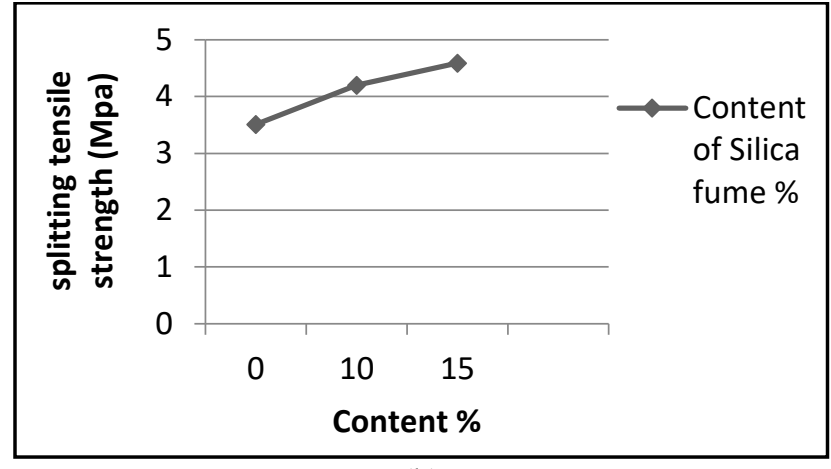

(b)

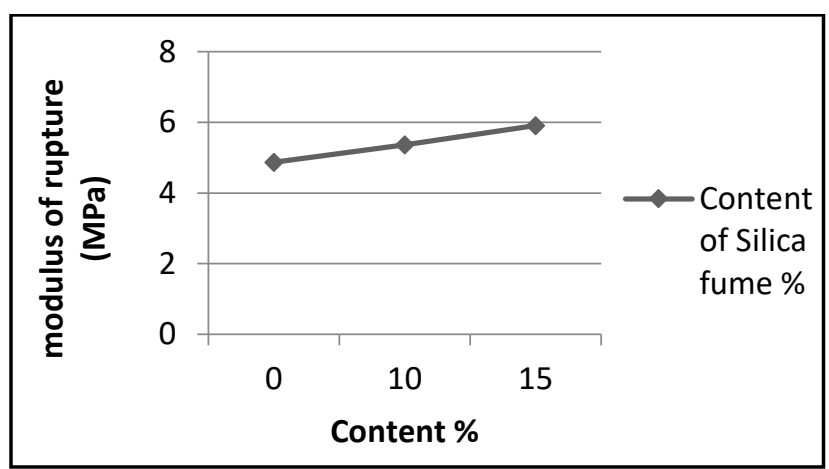

(c)

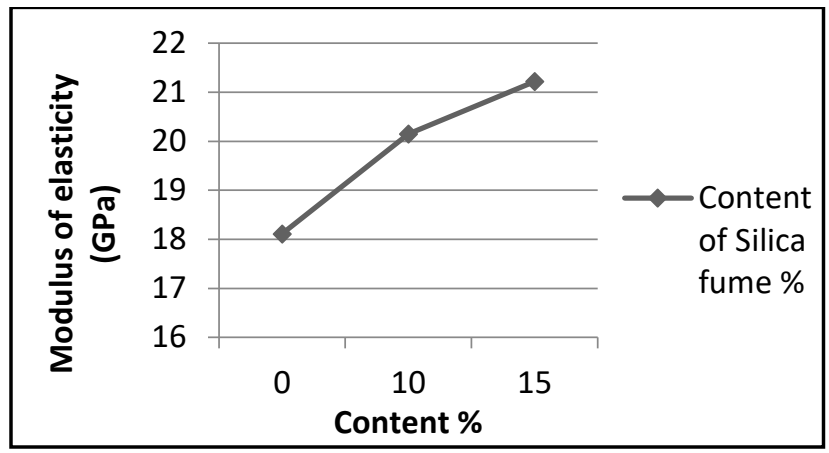

(d)

Figure 4. Result of mechanical properties, (a) Compressive strength, (b) Splitting tensile strength, (c) Modulus of rupture and (d) Modulus of elasticity

Table 8. and figure 5 show the results of the first cracking load and ultimate loads of LWSCC beams tested. The first cracking load increasing about by $13 \%$ and $42 \%$ compare with beam B1R when $10 \%$ and $15 \%$ of the silica fume were added for B2 and B3 respectively. The increase in the silica content in LWSCC mixtures leads to an improvement in the microstructure and increase the density due to the pozzolanic reaction of the silica. The maximum first cracking and ultimate load are recorded as $27 \mathrm{KN}$ and $177.5 \mathrm{KN}$ by addition $15 \%$ of silica fume in the mixture (M3) respectively. The results showed that increasing the $(\mathrm{a} / \mathrm{d})$ ratio leads to a decrease in the first cracking load and the ultimate loads. Three beams (B1R, B4, and B5) with different ratios of $(\mathrm{a} / \mathrm{d})$ were changed from 2.5 to 2.75 and 3.00 respectively. The variation of $(\mathrm{a} / \mathrm{d})$ from 2.5 to 2.75 resulted in decreasing percentage by (21) \% for first crack and (18) \% for the ultimate load (B4). The variation (a/d) ratio from 2.5 to 3.00 resulted in decreasing percentage by (34) \% and (25) \% respectively for first crack and the ultimate load (B5).

Table 8. Results of first cracking load and Ultimate load

\begin{tabular}{lllll}
\hline Beam & $\begin{array}{l}\text { First } \\
\text { crack }\end{array}$ & $\begin{array}{l}\text { Compare } \\
\text { WithB1 \% }\end{array}$ & $\begin{array}{l}\text { Ultimate } \\
\text { Load }\end{array}$ & $\begin{array}{l}\text { Compare } \\
\text { With B1 }\end{array}$ \\
& KN & & KN & $\%$ \\
B1R & 19 & - & 155 & - \\
B2 & 21.5 & 13 & 160 & 3 \\
B3 & 27.0 & 42 & 177.5 & 15 \\
B4 & 15 & 12 & 127 & 18 \\
B5 & 12 & 34 & 116 & 25 \\
\hline
\end{tabular}

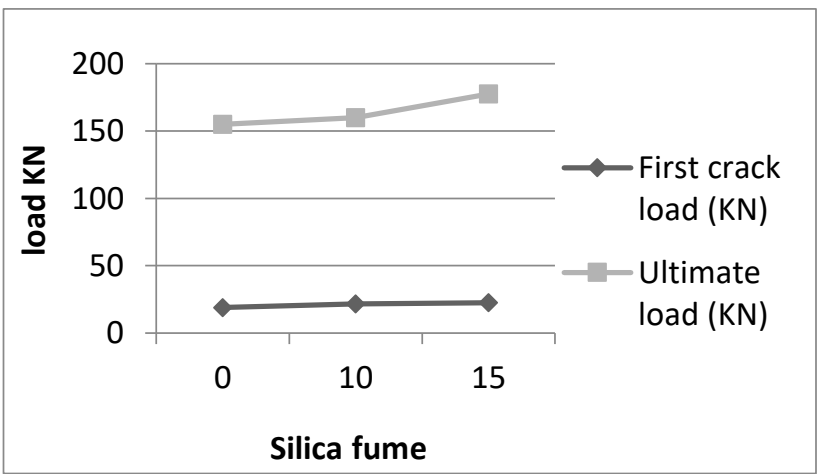

(a) 


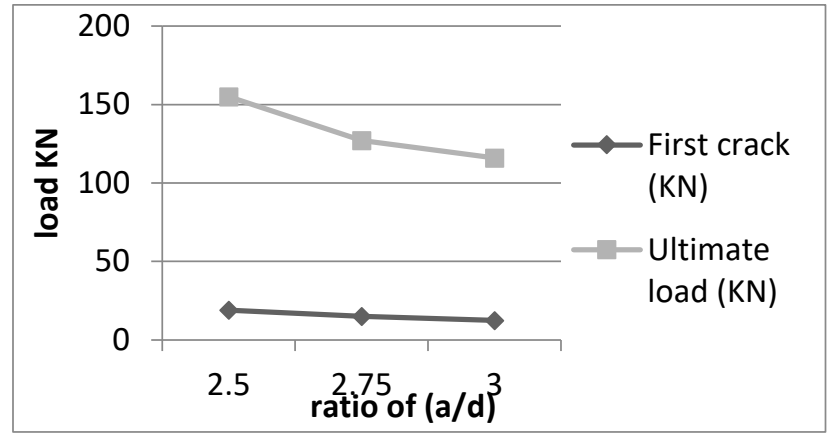

(b)

Figure 5. Development in first crack and ultimate load of LWSCC beams: (a) content of silica fume and (b) the ratio of $(\mathrm{a} / \mathrm{d})$

Table 9. and Figure 6 show the effect of the axial force on the lightweight self-compacting concrete beams, which led to an improvement in the capacity of the concrete and its resistance to applied loads. Regardless of the axial load applied on the beams tested, the stiffer loaddeflection curves are obtained from the beams with smaller $(\mathrm{a} / \mathrm{d})$ ratios. The beams with smaller (a/d) ratios are failed at lower deflection compared with the beams with larger $(\mathrm{a} / \mathrm{d})$ ratios. The beam (B1R) has $(\mathrm{a} / \mathrm{d})$ of 2.5 and failed when deflection equal $5.8 \mathrm{~mm}$, while the beams (B4 and B5) have (a/d) (2.75 and 3.00) respectively and failed at the deflection (7.71 and 8.15) $\mathrm{mm}$ respectively. The maximum load of (B4 and B5) decreases about (18\% and $25 \%$ ) due to early failure by concrete crushing. The axial load was beneficial for the LWSCC beams under bending it reduces tensile stresses on the bottom part of the beams. Illustrated by figure 6 (a) that the deflection increase with an increase in the silica fume under applied load. This is due to filling the voids between the concrete particles and addition to the chemical action of the silica fume, which leads to an increase in the compressive strength of the concrete. Silica fume was added to know the change in shear strength when the compressive strength rises under the influence of the axial load. In addition, found in figure 6. (B) that the slope of the deflection curve increases under axial load with the lower $(\mathrm{a} / \mathrm{d})$ ratio.

Table 9. Mid span deflection at first crack and ultimate

\begin{tabular}{llll}
\multicolumn{3}{c}{ load } \\
\hline Beam & Max & \multicolumn{1}{c}{$\Delta \mathbf{c r}$} & \multicolumn{1}{c}{$\Delta \mathbf{u}$} \\
No. & Crack(mm) & $(\mathrm{mm})$ & $(\mathrm{mm})$ \\
B1R & 0.18 & 0.92 & 5.8 \\
B2 & 0.15 & 0.3 & 4.99 \\
B3 & 0.2 & 0.9 & 6.61 \\
B4 & 0.35 & 0.49 & 7.71 \\
B5 & 0.3 & 1.11 & 8.15 \\
\hline
\end{tabular}

Figure (7) shows, in the early stages of the loading, the vertical curvature cracks are observed on the underside of the mid-span of the beam with increasing loading, shear cracks grow from the upper end of the bending cracks to configure flexural-shear cracks. In the late stages of the loading, the critical diagonal crack extended towards the loading points and producing a shear compression failure. After that, these cracks spread and penetrate the beam compression area, where the concrete is crushing at the tip of the diagonal crack in the load application area. This failure occurs when the compressive strength of concrete is exceeded. This type of failure is called shear compression failure, which occurs due to the crushing of the concrete at the loading point's. When the reinforcement is yielded, the load distribution is not possible and the concrete reaches its ultimate capacity which leads to crushing at the loading points. Shear compression failure occurred in all beams except for B3 and B4, It failed by crushing due to the increase in the bearing strength of the tensile area in the mid-span of the beam extension resulting from the effect of the axial force, where the axial force increased the shear capacity and the flexural resistance of the beam. Shear compression failure occurred in all beams except for B3 and B4, It failed by crushing due to the increase in the bearing strength of the tensile 
area in the mid-span of the beam extension resulting from the effect of the axial force, where the axial force increased the shear capacity and the flexural resistance of the beam. The maximum crack width decreases in the silica content of $10 \%$ and then the crack width increases in the silica content of $20 \%$, but in general, the silica is used to reduce the width of the crack due to the filling of the voids inside the concrete. Figure 7. Shows the failure mode and the crack width of the LWSCC beams.

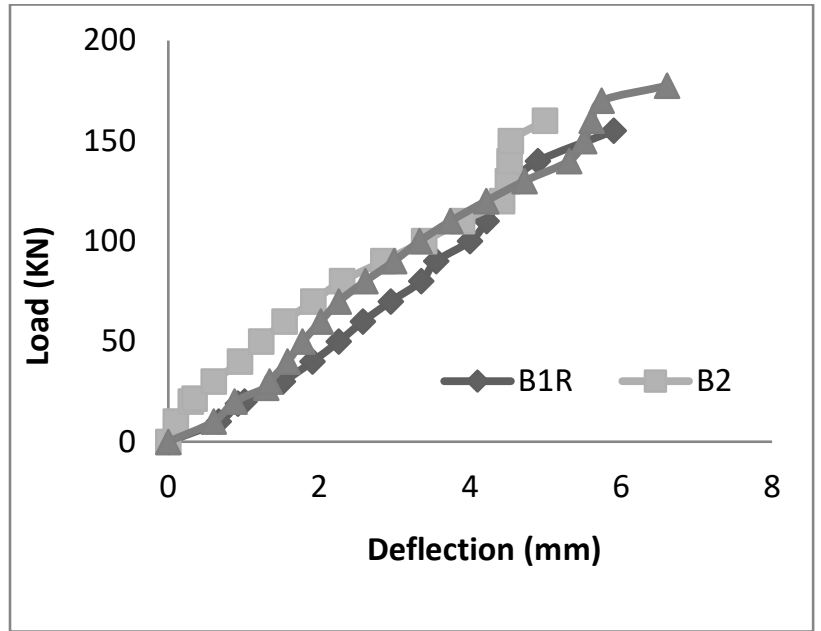

(a)

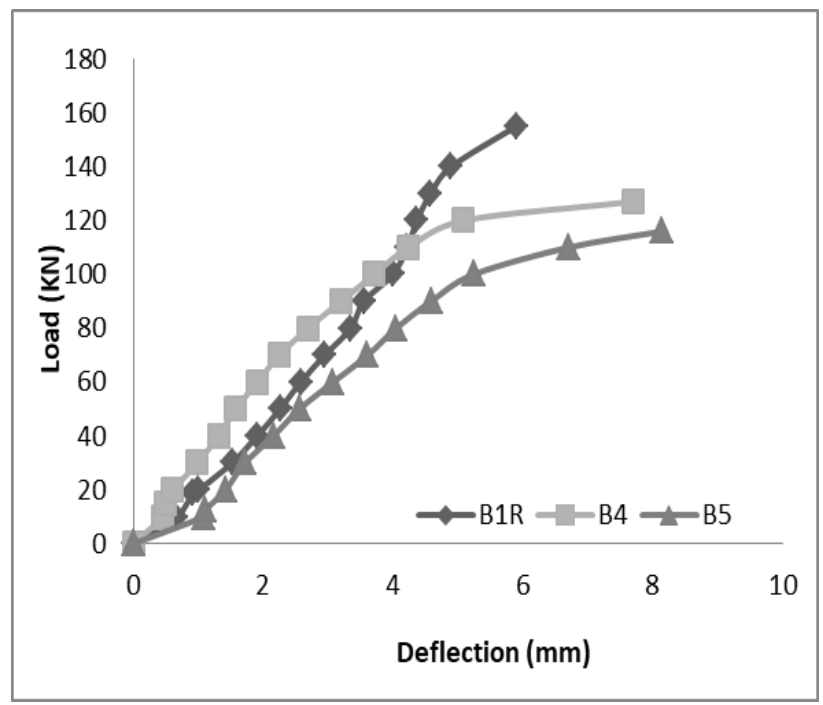

(b)

Figure 6. (a) and (b) Effect of silica fume and (a/d) on behavior Deflection at mid span

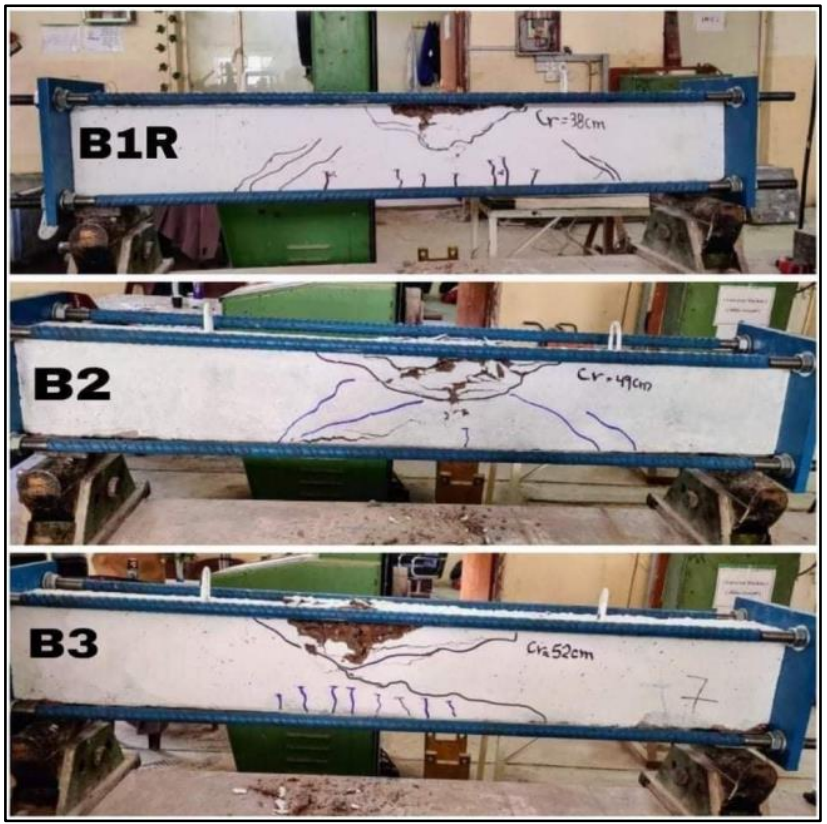

(a)

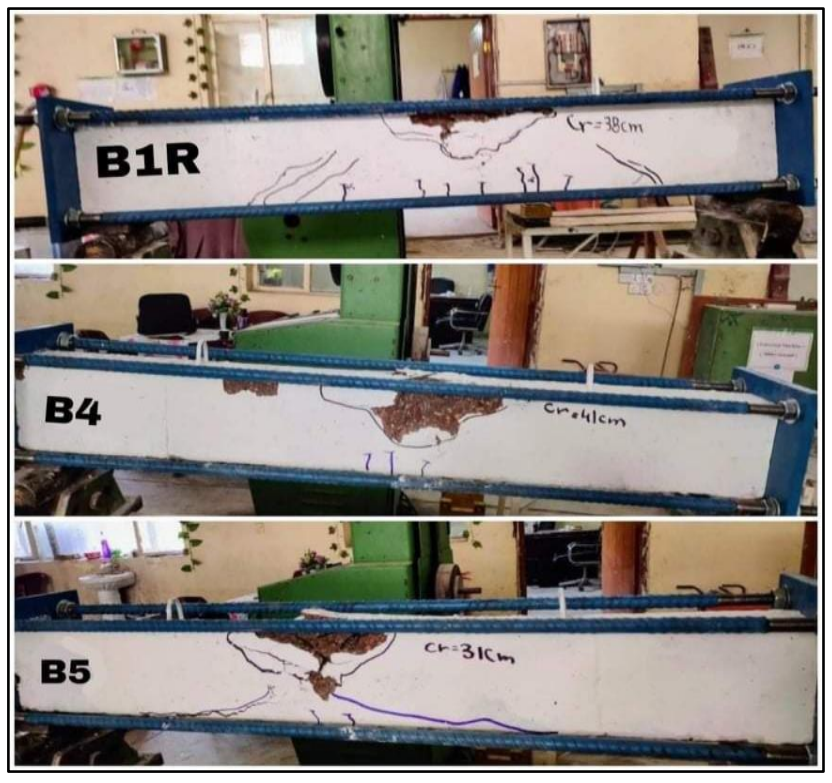

(b)

Figure 7. (a) Effect of silica fume and (b) (a/d) on Failure mode of beams

\section{Conclusions}

1. It is possible produce lightweight selfcompacting concrete by using Attapulgite as a coarse lightweight aggregate within the conformity to EFNARC 2005 for SCC workability and within the requirements of ASTM C 330-04 for structural (LWAC). 
2. The effect of silica fume for LWSCC mixtures that filling of the voids between concrete due to its high softness of silica fume.

3. Improvement about $22 \%, 31 \%, 21 \%$ and $17 \%$ in compressive strength. Splitting tensile strength, modulus of rupture and modulus of elasticity of LWSCC respectively when $15 \%$ addition of silica fume.

4. By studying the variables on lightweight, self-compacting concrete to improve sample loading capacity compared to the reference beam, the highest increase was found by adding $15 \%$ of silica fume.

5. As $(\mathrm{a} / \mathrm{d})$ increases, the first crack and Ultimate loads decreasing, and the crack width values increase with decreasing (a/d).

6. This test shows that concrete models consisting of lightweight self-compacting concrete beams have increased shear capacity and resistance to bending, due to the effect of axial load.

\section{Abbreviations}

$\begin{array}{ll}\text { LWC } & \begin{array}{l}\text { Lightweight concrete } \\ \text { SCC }\end{array} \\ \text { LWSCC } & \begin{array}{l}\text { Lightweight } \\ \text { compacting concrete } \\ \text { Reference conventional } \\ \text { concrete } \\ \text { NWC }\end{array} \\ \text { HRM } & \begin{array}{l}\text { Normal weight concrete } \\ \text { (a/d) }\end{array} \\ \text { OPC } & \begin{array}{l}\text { Ratio of the shear span to the } \\ \text { effective depth } \\ \text { fć }\end{array} \\ \text { Or } & \text { Cylinary Portland Cement } \\ \text { fr } & \text { strength Compressive } \\ & \text { Splitting tension strength } \\ & \text { Modulus of rupture }\end{array}$

$\begin{array}{ll}\text { Ec } & \begin{array}{l}\text { Modulus of elasticity } \\ \text { Mid- span deflection at } \\ \Delta \mathrm{u}\end{array} \\ \text { ultimate load } \\ \text { Mid-span deflection at first } \\ \text { crack } \\ \mathrm{SF} & \text { Silica fume } \\ \mathrm{VP} & \text { Volcanic pumice }\end{array}$

\section{Conflict of Interest}

The authors confirm that the current paper's publication does not result in a conflict of interest.

\section{References}

1. Zongjin, Li. (2011). "Advanced concrete technology". Hoboken, New Jersey, pp.1.

2. ACI Committee 213. (2014). "Guide for structural lightweight-aggregate concrete (ACI 213R-14)". American Concrete Institute.

3. Ozawa, K., Maekawa, K., Kunishima, M., and Okamura, H. (1989). "Development of high performance concrete based on the durability design of concrete structures". Proceedings of the 2nd East-Asia and Pacific Conference on Structural Engineering and Construction, (EASEC-2), 1, pp. 444-450.

4. AL-Noaimi, Kawkab. (2009). "Influence of the activated Qatari attapulgite clay admixture on the mechanical properties and hydration kinetics of the ordinary Portland cement". Qatar University. Sci. j. PP. 23-35

5. Jar-Allah Q. Hachim. (2011). "The effect of different types of aggregate and additives on the properties of self-compacting lightweight concrete". M.S.C. Thesis, University of Baghdad, Feb., pp. 112-115. 
6. Hossain, K. M. A. (2004). "Properties of volcanic pumice based cement and lightweight concrete". Cement and concrete research, 34(2), PP. 283-291.

7. Tang, C. W., Yen, T., and Chen, H. J. (2009). "Shear behavior of reinforced concrete beams made with sedimentary lightweight aggregate without shear reinforcement". Journal of materials in civil engineering, 21(12), PP.730-739.

8. Garcia, S. L. G., Lannes, C. V., Carneiro, L. A. V., and Lara, R. C. (2020). "Shear behavior of lightweight self-consolidating reinforced concrete beams without transverse reinforcement". Latin American Journal of Solids and Structures, 17(4).

9. Iraqi Specifications No. 5. (2019). "Portland cement". The Iraqi Central Organization for Standardization and quality Control, Baghdad-Iraq.

10. Iraqi Specification, No.45. (1984). "Aggregate from natural sources for concrete". Central Agency for Standardization and Quality Control, Planning Council, Baghdad, Iraq.

11. ASTM Designation C494-99a. (2001). "Standard specification for chemical admixtures for concrete". Annual Book of ASTM Standards, American Society for Testing and Material, Philadelphia, Annual Book of ASTM Standards, vol. 04.02.

12. ASTM-C1240, (2001). "Standard test methods for chemical, mass spectrometric, and spectro chemical analysis of nucleargrade uranium dioxide powders and pellets". Annual Book of ASTM Standards,
American Society for Testing and Material, Philadelphia, Pennsylvania, vol. 12.01.

13. ASTM A615. (1986). "Standard specification for deformed and plain billetsteel bars for concrete reinforcement". Annual Book of American Society for Testing and Material Standards, vol. 4, issue 1 .

14. ASTM A82. (2005). "Standard Specification for Steel Wire, Plain, for Concrete Reinforcement". ASTM Conshohocken, PA, 4PP.

15. EFNARC. (2005). "Specification and guidelines for self-compacting concrete". Association House, 99 West Street, Farnham, Surrey GU9, 7EN, UK, PP.21.

16. ASTM C39/C 39M-05. (2005). "Standard test method for compressive strength of cylindrical concrete specimens". Annual Book of ASTM Standards, Vol.04.02, Concrete and Aggregates, West Conshohocken, PA, United State, pp.1-7.

17. ASTM C 496-86. (2003). "Standard test method for splitting tensile strength of cylindrical concrete specimens". Annual Book of ASTM Standards, Vol. 04.02, pp.259-262.

18. ASTM C 78-84. (2003). "Standard test method for flexural strength of concrete using simple beam with two points loading". Annual Book of ASTM Standard, Vol. 04.02.

19. ASTM C469-87a. (1989). "Standard test method for static modulus of elasticity and poisson's ratio of concrete in compression". Annual Book of ASTM Standards, Vol. 04-02, PP.236-289. 